\section{Treatment of ethylene glycol poisoning with peritoneal dialysis}

Ethylene glycol is commonly available as a constituent of antifreeze solutions and is itself non-toxic. Since, however, the ingestion of over about $100 \mathrm{ml}$ ethylene glycol $(1.8 \mathrm{~mol} ; 110 \mathrm{~g})$ in an adult is potentially lethal owing to the production of toxic metabolites, treatment with an inhibitor of ethylene glycol metabolism, of which ethanol is the most convenient, should be started as soon as is practicable. Peritoneal dialysis or haemodialysis is also indicated to enhance the elimination of unchanged ethylene glycol and possibly also its metabolites, especially since renal impairment is one of the first serious manifestations of poisoning with this compound. There have been few reports ${ }^{15}$ of the use of dialysis in such cases, however, and the amount of ethylene glycol recovered was calculated in only two patients, one a child treated with peritoneal dialysis ${ }^{4}$ and one an adult treated with glycol concentration in excess of $8 \mathrm{mmol} / 1(0.5 \mathrm{~g} / \mathrm{l})$, that the patient is at serious risk from ethylene glycol toxicity.

We thank Mr A Huggett and Mr E Essex for technical help, and Professor $\mathrm{H}$ Keen, Dr C L Joiner, and Dr J Walls for allowing us to report details of patients admitted under their care.

${ }^{1}$ Schreiner GE, Maher JF, Marc-Aurele J, Knowlan D, Alvo M. Ethylene glycol-two indications for hemodialysis. Trans Am Soc Artif Intern Organs $1959 ; 5: 81-9$.

${ }^{2}$ Underwood F, Bennett WM. Ethylene glycol intoxication: prevention of renal failure by aggressive management. $\mathcal{F} A M A$ 1973;226:1453-4.

${ }^{3}$ Parry MF, Wallach R. Ethylene glycol poisoning. Am $\mathcal{F}$ Med 1974 ;57: $143-50$

4 Vale JA, Widdop B, Bluett NH. Ethylene glycol poisoning. Postgrad Med 7 1976;52:598-602.

${ }^{5}$ Peterson CD, Collins AJ, Himes JM, Bullock ML, Keane WF. Ethylene glycol poisoning-pharmacokinetics during therapy with ethanol and haemodialysis. N Engl f Med 1981;304:21-3.

Ditails of three patients poisoned with ethylene glycol and treated with peritoneal dialysis

\begin{tabular}{|c|c|c|c|c|c|c|}
\hline $\begin{array}{l}\text { Case } \\
\text { No }\end{array}$ & $\begin{array}{c}\text { Age (years) } \\
\text { and sex }\end{array}$ & $\begin{array}{l}\text { Approximate } \\
\text { amount of } \\
\text { ethylene glycol } \\
\text { ingested } \\
(\mathrm{mol})\end{array}$ & $\begin{array}{l}\text { Pre-dialysis } \\
\text { ethylene glycol } \\
\text { plasma } \\
\text { concentration } \\
(\mathrm{mmol} / \mathrm{l})\end{array}$ & $\begin{array}{l}\text { Duration of } \\
\text { peritoneal } \\
\text { dialysis } \\
\text { (hours) }\end{array}$ & $\begin{array}{l}\text { Amount of } \\
\text { ethylene glycol } \\
\text { removed by } \\
\text { peritoneal } \\
\text { dialysis } \\
\text { (mol) }\end{array}$ & $\begin{array}{c}\text { Renal excretion } \\
\text { of ethylene glyco } \\
\text { during peritoneal } \\
\text { dialysis } \\
(\mathrm{mol})\end{array}$ \\
\hline $\begin{array}{l}1 \\
2 \\
3\end{array}$ & $\begin{array}{ll}39 & \mathrm{~F} \\
51 & \mathrm{M} \\
56 & \mathrm{M}\end{array}$ & $\begin{array}{l}2 \cdot 74 \\
5 \cdot 48 \\
2 \cdot 74\end{array}$ & $\begin{array}{r}46 \cdot 8 \\
106 \cdot 5 \\
40 \cdot 3\end{array}$ & $\begin{array}{l}65 \\
41 \\
99\end{array}$ & $\begin{array}{l}0.61 \\
2.27 \\
0.89\end{array}$ & $\begin{array}{l}0.66 \\
0.34 \\
0.31\end{array}$ \\
\hline
\end{tabular}

Conversion: SI to traditional units-Ethylene glycol: $1 \mathrm{~mol} / 1 \approx 62 \cdot 1 \mathrm{~g} / \mathrm{l}$.

haemodialysis. ${ }^{5}$ We report on three adult patients treated with peritoneal dialysis on whom full analytical data were collected.

\section{Patients, methods, and results}

Plasma, peritoneal dialysis fluid, and urinary ethylene glycol concentrations were measured by gas chromatography. ${ }^{4}$ All three patients were treated with intravenous sodium bicarbonate and ethanol. Peritoneal dialysis was started as soon as possible after admission and was continued until the plasma ethylene glycol concentration fell below $1.6 \mathrm{mmol} / 1(0.1 \mathrm{~g} / 1)$. In all cases ethanol at a concentration of $21 \cdot 7-43.5 \mathrm{mmol} / 1(1-2 \mathrm{~g} / \mathrm{l})$ was added to the dialysate to prevent removal of the infused ethanol. The results are summarised in the table. Two patients (cases 1 and 3) made full recoveries. The remaining patient required a total of $2 \mathrm{~mol}(168 \mathrm{~g})$ sodium bicarbonate in order to maintain the arterial $\mathrm{pH}$ between $7 \cdot 2-7 \cdot 3$ and, although haemodialysis and ultrafiltration were performed to remove excess sodium, he died from multiple organ failure. One patient (case 3) had a one-month history of weight loss, polyuria, and polydipsia and required treatment with insulin (blood glucose concentration $14.5 \mathrm{mmol} / \mathrm{l}(261 \mathrm{mg} / 100 \mathrm{ml})$ on admission). In addition, he needed sedation and elective ventilation for the first 18 hours of peritoneal dialysis.

\section{Comment}

Peritoneal dialysis for eight days in a $2 \frac{1}{2}$-year-old child who had ingested about $1.8 \mathrm{~mol}(110 \mathrm{~g})$ ethylene glycol removed $0.43 \mathrm{~mol}$ $(26.9 \mathrm{~g}){ }^{4}$ a similar proportion of the total dose to that removed in the cases cited here, and the child made a full recovery. While peritoneal dialysis may not be as efficient as haemodialysis in removing ethylene glycol (Peterson et al ${ }^{5}$ reported that haemodialysis for six hours in a 51 -year-old man who had ingested about $9 \cdot 7 \mathrm{~mol}(600 \mathrm{~g})$ ethylene glycol removed $1.8 \mathrm{~mol}(111 \mathrm{~g})$, while urinary excretion was $0.16 \mathrm{~mol}(10 \mathrm{~g})$ during this period), clearly appreciable quantities of ethylene glycol were removed by peritoneal dialysis in our patients. Thus, in patients severely poisoned with ethylene glycol we believe that in addition to gastric lavage, supportive measures to combat shock and respiratory distress, the correction of metabolic acidosis and hypocalcaemia, and the use of ethanol, the early application of dialysis will remove substantial amounts of ethylene glycol and may prevent death. If haemodialysis is not immediately available then peritoneal dialysis is an effective alternative and should be instituted without delay when it is certain, on the basis of the clinical features and a plasma ethylene
(Accepted 26 October 1981)

\section{Guy's Hospital, London SE1 9RT}

J A VALE, MD, MRCP, senior medical registrar

J G PRIOR, MB, MRCP, registrar in clinical toxicology and intensive care (now senior registrar in thoracic and general medicine)

J P O'HARE, MB, BS, house physician (now junior lecturer in medicine)

R J FLANAGAN, BSC, senior biochemist, poisons unit

Leicester General Hospital, Leicester LE5 4PW

J FEEHALLY, MB, MRCP, registrar in nephrology

\section{Lupus foot}

Articular symptoms are the most common clinical manifestation of systemic lupus erythematosus as well as the most frequent manner of presentation. ${ }^{1}$ Up to $95 \%$ of patients with systemic lupus erythematosus have arthralgia or arthritis at some stage of their disease, ${ }^{2} 3$ and in $74 \%$ more than two joints may be affected. ${ }^{4}$ Symmetrical distribution is typical, and the joints most commonly affected in order of frequency are the finger proximal interphalangeal, knees, wrists, and metacarpophalangeal. Deformity may be severe, but bone and cartilage damage is uncommon and erosions rare. ${ }^{13}$ Radiologically the main abnormality is subluxation, and the underlying pathology is thought to be contracture of tendons and laxity of the joint capsule.

We report on three patients with deformities and radiological changes in both feet due to systemic lupus erythematosus. We are not aware that this has been previously reported.

\section{Case reports}

Case 1-A 35-year-old Cypriot woman had had systemic lupus erythematosus for 14 years; throughout the course of her disease a prominent feature had been synovitis affecting the hands and feet. Deformity of the hands had developed at an early stage, and over the past three years her feet had become progressively abnormal (figure). Radiologically there were subluxa- 